International Symposium on Open,

Distance, and e-learning (ISODEL) 2018

\title{
ORGANIC CHEMISTRY 1 DIGITAL BOOK
}

\author{
Dewi Handayani \\ Chemistry Study Program \\ Faculty of Teacher Training and Education,University of Bengkulu, \\ Bengkulu, Indonesia \\ Supratman Street, Bengkulu, Indonesia 38371A \\ Email: d.handayani@unib.ac.id
}

\begin{abstract}
The presents study was inteded to develop the Organic Chemistry 1 digital book with the help of the ePub editor Sigil application. This research is a type of research and development $(R \& D)$. The research procedure refers to the development strategy including the ones, research and information collecting; planning; develop preliminary from of product; preliminary field testing; main product revision; main filed testing; operational product revision; operational field testing; final product revision; dissemination and implementation. The results showed that development of this organic chemistry 1 digital book has been successfully created. Field trials to larger classes were carried out after revising digital books developed based on input from the expert team. The final stage is the improvement of the organic chemical 1 digital book product, as well as monitoring the distribution of digital books that have been developed for quality control. Based on the response given by the students, it states that this digital book is very good. This is indicated by the positive response of students to the book that has been made at $87 \%$. Students stated that this digital book is very good to be used to study independently. The advantages of this digital book include open and free formats. The tools to read it are available on various devices. Can enter video and sound, it looks attractive, text settings are easy and can be taken anywhere because it is available in the form of files.
\end{abstract}

Keywords: Digital Books, Organic Chemistry 1, ePub editor Sigil application 


\section{INTRODUCTION}

Organic Chemistry 1 is a compulsory subject that must be followed by Chemistry Education Program Study students. At present, the teaching materials available for Organic Chemistry 1 courses are still very limited. Therefore, teaching materials were made in the Organic Chemistry 1 course using the ePub editor sigil application. This teaching material in the form of a digital book can later be used as a reference for lecturers, Chemistry Study Program students, Biology Study Program students and other students taking courses in Organic Chemistry.

Electronic publication (Epub) is one of the digital book formats agreed upon by the International Digital Publishing Forum (IDPF) in October 2011. Epub replaced the role of Open eBook as an open book format. Epub consists of multimedia files, html5, css, xhtml, xml which are packaged in one file. (Southeast Asian Ministers of Education Organization Regional Open Learning Centre (SEAMEO SEAMOLEC),2014:5). E-books can be read by using computers, laptops and even mobile devices. A wide variety of e-book format has been used but only e-pub can suitable for various screen size of mobile devices. Then e-pub is a standard format that have been introduced by International Digital Publishing Forum (IDPF) on October, 2011 with SIGIL as an application editor. Sigil is an Open Source editor that available for all writers and readers. (Hidayat, dkk. 2017).

Based on the results of research conducted by Joo, et al ( 2017), the study found that (a) the more expectations of digital textbooks are satisfied, the more likely students are to perceive enjoyment and usefulness of digital textbooks, (b) satisfaction plays a mediating role in linking expectation, perceived enjoyment and usefulness, and continuance intention to use digital textbooks, (c) perceived usefulness and satisfaction have a direct and positive influence on continuance intention to use digital textbooks, and (d) perceived enjoyment has a non-significant influence on continuance intention to use digital textbooks with middle school students. Based on these findings, the implications and recommendations for future research are presented. According to Astuti and Kusumajanto (2017), electronic book will be help student in order to understand material and student study sources individually. This electronic book EPUB-based provide formative exercise to add knowledge and train student's creativity with several tasks about display implementation and displayapplication.

The development of this digital book is interesting because it can be carried everywhere because it is available as a file. Open and free format means easy to get and cheap. The reading tool is available on various devices. Can enter video and sound, so that students can enjoy it independently.Attractive appearance and easy text settings. Students and lecturers can open this application via computers, laptops and mobile phones. It can be read anytime and students can be motivated to diligently open digital books because they can be seen directly on their mobile phones.

Related research that was also carried out by researchers (Handayani, 2017) state that the development of instructional media in the organic chemistry 1 is inseparable from the role of multimedia that produces an information in the form of images, sounds, andanimationssothattheroleofmultimediaisveryhelpfulin 
information distributors. In this digital book not only can be in the form of pdf files, but also can be included files in the form of power point, learning videos, macromedia flash animation media and so on.

This research is important, because it can produce teaching materials products, namely in the form of digital books, especially in the course of Organic Chemistry. The results are expected to provide a complete reference for this course so that it can be used by lecturers and students in need. The application used in this study was using Sigil. This application can be downloaded on the website https://code.google.com/p/sigil/.

\section{LITERATURE REVIEW}

Media is an intermediary or introduction to the message sender to the recipient of the message. Gagne states that media are various types of components in the environment of students who can stimulate them to learn. Meanwhile, Briggs argues that media are all physical tools that can present messages and stimulate students to learn. Books, films, tapes, frame films are examples. (Sadiman, dkk, 2009).

Learning media is everything that can be used to convey messages or information in the teaching and learning process so that it can stimulate students' attention and interest in learning. Gagne and Briggs (Arsyad, 2014) implicitly say that learning media includes tools that are physically used to convey the contents of teaching materials, which consist of books, tape recorders, tapes, video cameras, video recorders, films, and so on.

Sukiman (2012: 44) says learning media is a component of learning that includes materials and equipment. With the influx of influences into the world of education (for example new theories / concepts and technology), learning media continue to experience development and appear in various types and formats, with each of their own characteristics and abilities. Based on the understanding of learning media that has been stated above, it can be concluded that, learning media are all ways that are used by teachers to help deliver learning material to students to stimulate students in learning, can be books, videos, or school environment.

Teaching materials are a set of material/ substance lessons that are arranged systematically, displaying a complete figure of competencies that will be mastered by students in learning activities. The existence of teaching materials allows students to learn a competency or basic competency in a coherent and systematic manner so that accumulatively able to master all competencies as a whole and integrated.

Digital books, or also called e-books, are publications consisting of text, images, and sounds and are published in digital form that can be read on computers or other electronic devices. A digital book is usually an electronic version of a printed book, but not infrequently a book is only published in digital form without a printed version. 

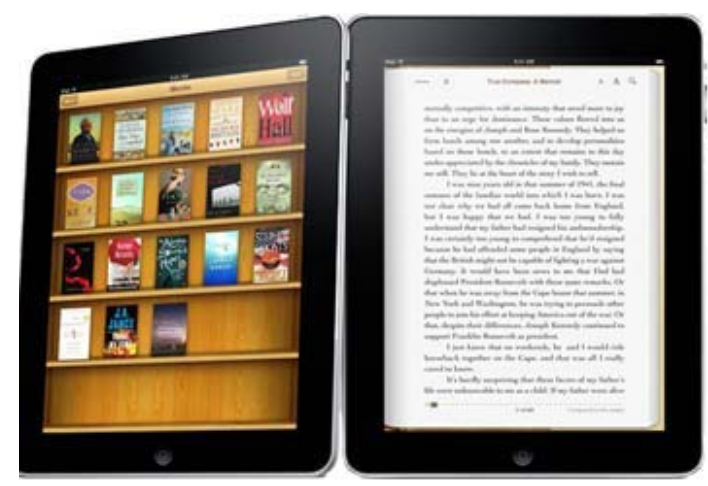

Figure 1. Display of digital books

The format of digital books varies, ranging from formats supported by large companies (PDF by adobe, swf by flash, doc by Word) and various other formats supported by certain digital book readers and devices. In 1990 also developed an open e-book format that allows publishers and software developers to use one format that can be read on any device and use various digital book reader software.

E-books or e-books are textbooks that are converted into digital formats, ebooks also have the meaning of a learning environment that has applications that contain multimedia databases instructional resources that store multimedia presentations about topics in a book. (Shiratuddin, et al. 2003).

E-books with epub format are more dynamic than other formats, because the size of the text, page numbers, images and paragraphs always adjust the screen of the device used by the reader. This e-book with epub format is not a book that is not ready to print but makes it easier for writers to publish it at low cost and the convenience of readers can access the contents of books wherever using mobile devices from any page with a table of contents, which makes the reader feel like read printed books normally (Hidayat et al. 2017).

ePUB (electronic publication) is one of the standard digital book formats introduced by the International Digital Publishing Forum (IDPF) in October 2011. ePUB replaces the role of open eBook as an open book format consisting of multimedia files, html5, css, xhtml, xml which put together into one digital book file (Suryani et al. 2018). The various advantages Epub has to offer have made Epub one of the most widely used digital book formats, features include: (a) Open and free formats, (b). Various epub readers are available on various devices, (c). Various epub-making software is available, (d). Support for video and audio, (e). Reflowable (word wrap), and text size settings, (f). Support for DRM, (g). CSSstyling.

\section{METHOD}

This research using Research and Development (R\&D) method. Research and Development is a process or steps to develop a new product or improve existing products, which can be accounted for (Sukmadinata, 2005), a process that Applies 
knowledge to create new devices on effects (Bock, 2001), to develop and validate the products used in education (Borg \& Gall, 2003).

This research done at Chemistry Education Study Program, University of Bengkulu Organic Chemistry 1 class. Electronic book design EPUB-Sigil application based. This research was conducted in a university located in the southwest part of Sumatra Island, Indonesia. The sample in this research is the third semester student of Chemistry Education Study Program of academic year 2018/2019. Thirty eight students ( 3 males and 35 females) who enrolled in the Organic Chemistry Course participated in this researchproject.

Research method of development in this research as according puslitjaknov (2008: 8) consists of 3 main components, namely; development model, procedure development, and product testing. The stages of the research are (a). Pre-survey to gather information, (b).Conduct planning (identifying problems, formulating a business plan), (c). Develop the type / form of the initial products, (d). To test the initial stage, (e). Performing revision of the main product, (f). Perform the main field trials, (g). Perform revision of the products, (h). Conduct operational field, (i). Revise the final product, (j). Disseminate and implement theproduct.

Models of test or products consists of 3 stages (a). Expert test with the result of validation on inputs from the expert team of products to be developed, (b). The trial was limited in the experimental class with the test sample teaching the material with about 10 students and 2 observers further inputs for revised product improvements, (c). Field test.. In this field trial there must be peer observer.

The data collected in the form of inputs are poured in the questionnaire and the result checklist observation instruments that are recorded in accordance with its components. The feasibility of developed media products includes the criteria of a good multimedia component (Ashyar, 2011: 173). For the view of developed products will be seen also as Munir (2010: 244) stated the assessment of the software includes assessment of text, graphics, sound, music, video, and animation and learning activities in it.

The data analyzed is a description containing the inputs from the research objectives and quantitative calculations in the form of the percentage of the feasibility of product testing using the percentage of answer choice formula. Data analysis technique used is descriptive data analysis techniques, namely by describing validity, practicality and effectiveness of the development of the business plan. To describe the technique of frequency analysis of data by theformula:

$\%=\mathrm{n} / \mathrm{N} \times 100 \%$

Information:

$\mathrm{n}=$ Number of values obtained.

$\mathrm{N}=$ Total of all ideal values (number of respondents $\mathrm{x}$ highest score).

(Sugiyono, 2012: 137). 
Table 1. Descriptive Criteria Percentage Digital Book of Organic Chemistry 1

\begin{tabular}{ll}
\hline Percentage Intervale & Criteria \\
\hline $81,25 \%-100 \%$ & Very good \\
$62,5 \%-81,25 \%$ & Good \\
$43,75 \%-62,5 \%$ & Good Enough \\
$25 \%-43,75 \%$ & Not good \\
\hline
\end{tabular}

\section{RESULT AND DISCUSSION}

Teaching materials are a component that plays an important role in the learning process, but only a portion of lecturers use the help of teaching materials, most of them only use existing printed books. Therefore it is necessary to develop teaching materials that can motivate students to study hard even without the guidance of lecturers. Lecturers are expected not only to teach, conduct research and service, but also are required to be able to develop good teaching materials. The expected teaching material is teaching material that contains material that is complete with the device from the instructions to the evaluation. Good teaching materials/ modules are teaching materials that integrate instructions for learning manuals, multimedia, and even online sites that can be accessed by students (Yaumi, 2018).

Writing digital books for organic chemistry 1 courses begins with drafting a book. Before the book is used in the learning process, a validation and trial process is first carried out. If the results of the draft test book are declared feasible, then the book is ready to be implemented for the benefit of real learning. Conversely, if it is not feasible, repairs should be made as needed, according to the input during the trial. In this study, a digital textbook on Organic Chemistry has been successfully created. This book has been revised twice, according to input from a team of material and media experts. Making learning media using the help of sigilsoftware.

The Media Validation Questionnaire for Material Experts includes (1) Lessons criteria, the indicator is that it can be used for individual learning, small and large groups learning, topics in the program are clear and the learning approach can adjust the students. (2) Curriculum, the indicators are media in accordance with the material what is taught in learning and the media is relevant to the material students are studying. Media in accordance with the material taught in learning. The media is relevant to the material (3) Fill in the content, the indicator is the material concept is correct and precise and have a practice or tests problem. (4) Interaction, program structure is flexible to users and the program has a feedback from user-supplied input.

(5) Reverse, the indicator programs have varying responses so users do not get bored. Material experts in this matter are colleagues of the Organic Chemistry Lecturer at the University ofBengkulu.

The Media Validation Questionnaire for Media Experts, the criteria include (1) Criteria of program display, the indicators consist of display program, use of grammar, use of interactive functions, grapich, audio, animation/video and interface 
design containing 16 question number. (2). Criteria of tecnition quality, the indicator is the program operation and user response divided into 4 question numbers. Media experts are Developers in Learning Technology, LPMP. Bengkulu.

Grid of Media Feasibility Sheets for Students as Users. (1) Program display criteria, the indicator is the color use, the text in the program is clear, program language is easy to understand, Sound in the program clearly (2) Content, the indicator is Material concept is correct and correct and have practice or test questions. (3) Interaction, the indicator is Program has a reverse user-supplied input. (4) Reversed, the indicator is the program has a variative response.

The feasibility of e-sigil digital books reviewed by material / learning experts, media experts and students as users / users of learning media through assessment validation in the form of instruments, can be seen in table 2 below:

Table 2. Eligibility Based on Assessment Instruments

\begin{tabular}{clcll}
\hline No & Appraisal & $\begin{array}{c}\text { Result } \\
(\%)\end{array}$ & Criteria & Eligibility \\
\hline 1 & Expert & 90 & Very & Very \\
& material & & Good & Decent \\
\hline 2 & Media & 83 & Very & Very \\
& Experts & & Good & Decent \\
\hline 3 & Students & 87 & Very & Very \\
& & & Good & Decent \\
\hline
\end{tabular}

From table 2, it can be seen that the results of the validation of organic chemistry 1 digital book using the sigil application get the percentage of material experts, media and responses from students each at $90 \%, 83 \%$ and $87 \%$ with very feasible categories, meaning overall chemical digital books organic 1 which is presented is very suitable for use in teaching and learning activities.The revised results of the digital book after input from the expert team, including: (1). Repair lay out (2). Letter writing in the book (3). The color display and arrangement of books are improved (4). Add images that support the content of learning materials so that the book becomes more interesting. (5). Improved power point learning material. (6). Revision of the digital bookcover.

The results of student learning as many as 38 people after using this digital book include: 
Table 3. Learning Outcomes using Organic Chemistry 1 Digital Book

\begin{tabular}{|c|c|c|c|c|c|}
\hline $\begin{array}{c}\text { Numb } \\
\text { er }\end{array}$ & $\begin{array}{c}\text { Initial } \\
\text { stude } \\
\text { nt }\end{array}$ & $\begin{array}{c}\text { Po } \\
\text { stt } \\
\text { es } \\
t\end{array}$ & $\begin{array}{c}\text { Numb } \\
\text { er }\end{array}$ & $\begin{array}{c}\text { Initial } \\
\text { stude } \\
\quad n t\end{array}$ & $\begin{array}{c}\text { Po } \\
\text { stt } \\
\text { es } \\
t\end{array}$ \\
\hline 1 & $R M$ & 100 & 20 & $L K$ & 90 \\
\hline 2 & $D K$ & 70 & 21 & SK & 100 \\
\hline 3 & $A K$ & 80 & 22 & $D F$ & 90 \\
\hline 4 & $W K$ & 100 & 23 & $D M$ & 90 \\
\hline 5 & $A N$ & 80 & 24 & $A W$ & 70 \\
\hline 6 & $M R$ & 40 & 25 & $B M$ & 50 \\
\hline 7 & $T U$ & 90 & 26 & $G T$ & 70 \\
\hline 8 & $J K$ & 90 & 27 & $Y U$ & 100 \\
\hline 9 & $T I$ & 100 & 28 & $K L$ & 30 \\
\hline 10 & $D H$ & 90 & 29 & $\mathrm{HI}$ & 100 \\
\hline 11 & $M P$ & 100 & 30 & $J P$ & 100 \\
\hline 12 & $L I$ & 100 & 31 & $C C$ & 40 \\
\hline 13 & $K I$ & 70 & 32 & $M N$ & 100 \\
\hline 14 & GK & 70 & 33 & $O D$ & 100 \\
\hline 15 & $W K$ & 90 & 34 & $\mathrm{PH}$ & 100 \\
\hline 16 & $R D$ & 90 & 35 & $L M$ & 100 \\
\hline 17 & $T N$ & 100 & 36 & $R B$ & 100 \\
\hline 18 & $Y K$ & 90 & 37 & $K S$ & 100 \\
\hline 19 & $P O$ & 100 & 38 & $H Q$ & 80 \\
\hline
\end{tabular}

Based on the table 3 seen that this digital book has an effect on student learning outcomes. Already exceeding the minimum completeness criteria limit the value (70) achieved is 85.79. Although if seen from the distribution there are still some students whose grades have not been completed. By using this digital book students become more motivated in learning, because it makes it easier for students to read books using a laptop or mobile phone. In the digital book that has been made, it also contains learning material as outlined in the form of reading texts. In addition, it is also equipped with interactive media, namely learning videos, power points and other supporting animations. Pictures and colors are presented attractively so students are not bored and happy to read them. According to James OheneDjan (2003) an interactive e-book contains a network of digital information units consisting of text, graphics, video, animation or sound and questions that are all packaged in the form of flash animation visualization combined in one program and equipped with color, sound andmusic.

This research is in line with Astuti and Kusumajanto (2017) who stated that Student responds while using electronic book EPUB-based in learning activity shows that they are helped with study sources which electronic based, because easy to get 
and used in learning activity also outside learning activity individually using their own personal device.

In addition, digital books created also have questions that can be learned by students, as an exercise in mastering the material that has been received.These advantages of the digital book are as follows: a) Open and free format means easy to get and cheap, b) A tool to read it is available on various devices. c) Can enter video and sound, so that students can enjoy it independently. d) Looks attractive. e) Easy text settings. f) Can be carried everywhere because it is available as a file.This advantage is also expressed by Swandini et al. (2017), namely electro-textbooks that have good display quality applications, such as attractive graphic design, convenience of graphic display, accuracy of color use, conformity of text size and shape, precision of image proportions and animation effects, ease navigation buttons for browsing, and the right layout.

\section{CONCLUSION AND SUGGESTION}

From the results of the research, the organic chemistry 1 digital book for students of the Chemical Education Study Program FKIP UNIB has been created and validated by a team of experts. Based on the results of the feasibility test of organic chemistry digital books 1 in terms of the quality aspects of the appearance and aspects of technical quality by media experts, curriculum aspects and content aspects by material experts, the results of the assessment obtained are declared "very feasible". So from that this digital book is worthy of being used for learning organic chemistry 1 . The percentage scores of material experts and media experts are $90 \%$ (very good criteria) and $83 \%$ (very good criteria). Students as users state that media is very well used for independent learning. This is stated in the percentage of student responses to digital book media is $87 \%$. This digital book also influences student learning outcomes, namely the average student score of 85.79.

This research is a development research that is only carried out until the development stage. Therefore, further research is needed to carry out the dissaminate stage. 


\section{REFERENCES}

\section{Books}

Arsyad, Azhar. (2014). Media Pembelajaran. Jakarta: Rajawali Pers. ISBN : 978-979769-513-2.

Asyhar, R. (2011). KreatifMengembangkan Media Pembelajaran, Jakarta: GaungPersada Press

Bock, Peter. (2001). Getting It Right: R\&D Method in Science and Engineering. Sandiego: Academic Press.

Borg.W.R, Gall.M.D, \&Gall.J.P.(2003). Educational Research an Introduction Seventh Edition. USA: Pearson EducationINC.

Munir.(2010). KurikulumBerbasisTeknologilnformasidanKomunikasi.Bandung: CV Alfabeta.

Sadiman, Arief S, Rahardjo, AnungHaryono, danRahardjito. (2009). Media Pendidikan: Jakarta: Rajawali Pers. ISBN : 979-421-025-0.

Setiawan, Putria. (2018). Media pembelajaraninovatifdanpengembangannya. PT. RemajaRosdakarya : Bandung.

Southeast Asian Ministers of Educatioan Organization Regional Open Learning Centre (SEAMEO SEAMOLEC). (2014). BukuSumber:Buku Digital. Pelatihanbuku digital 26 maret2014.

Sugiyono.( 2014). MetodePenelitianKuantitatif, Kualitatifdan R\&D. Bandung: Alfabeta.

Sugiyono.(2012). MetodePenelitianPendidikan (PendekatanKuantitatif, Kualitatif, dan $R \& D)$.Bandung :Alfabeta.

Sukiman.(2012). Pengembangan Media Pembelajaran. Yogyakarta: Pedagogia.

Sukmadinata, Nana Syaodih. (2005). Methods of Educational Research.Remaja Rosdakarya: Bandung-Indonesia.

Yaumi, M. (2018).Media danTeknologiPembelajaran.Jakarta :Prenada Media Grup. 
PuslitaknovDepdiknas. (2008). MetodePenelitianPengembangan, Jakarta:Depdiknas

\section{Journals/ Proceedings/ Dissertations/Theses}

AstutidanKusumajanto.(2017). DEVELOPMENT OF ELECTRONIC BOOK (E-BOOK) EPUB-BASED FOR DISPLAY COURSE.JurnalPendidikan, BisnisdanManajemen. VOL 3, NO.2, SEPTEMBER201

Hidayat R, Erwadi, Sari VR, dan Ade VRP.(2017). Pemanfaatan Sigil UntukPembuatan E-Book.Jurnal TEKNOSI, Vol. 03, No. 01, April 2017. UniversitaAndalas : Padang Sumatera Barat.

James Ohene-Djan. (2003). Personalising Electronic Books. Journal of Digital Information, Vol 3, No 4

Joo,Park, Shin. (2017). Students' expectation, satisfaction, and continuance intention to use digital textbooks.commputers in Human Behavior. Volume 69, April 2017, Pages 83-90. Show more https://doi.org/10.1016/j.chb.2016.12.025

Shiratuddin, Norshuhadadkk.(2003). Ebook technology and its potential Application in Distance Education. Journal of Digital Information, Vol 3, No4

Swandini, Supraptono, Sukamtadan Nadir. (2017). PENGARUH BUKU AJAR ELEKTRONIK BERBASIS ANDROID PADA MATERI AJAR EKSPONENDAN LOGARITMA.Dinamika:

JurnalPraktikPenelitianTindakanKelasPendidikanDasar\&Menengah. Vol. 7, No. 1, Januari 2017.ISSN 0854-2172.

\section{Others}

Handayani, D. (2017). The Making of Organic Chemistry 1 Digital Books by Using The Sigil Epub Editor Application. Conference Proceeding BICSE 2017. ISBN : 978602-8043-84-7. Halaman 2442.Bengkulu.

\section{ABOUT THE AUTHORS}

Dewi Handayani: Lecturer, Chemistry Study Program, Faculty of Teacher Training and Education,University of Bengkulu, Bengkulu, Indonesia. 